\title{
Procalcitonina - Diagnostic Marker in Neonatal Sepsis
}

\author{
AMELIA MILULESCU1*, FLORIN DORNEANU², DANIELA IACOB3*, DANA STOIAN*, IZABELLA PETRE5*, \\ VERONICA DANIELA CHIRIAC ${ }^{5 *}$, ROXANA MARGAN ${ }^{5}$, IOANA IONITA ${ }^{6 *}$, DANIELA MARTI ${ }^{7}$, LAVINIA CRISTINA MOLERIU \\ 'University of Medicine and Pharmacy Carol Davila, Department of Obstetrics and Gynecology, 37 Dionisie Lupu Str., 030167, \\ Bucharest, Romania \\ ${ }^{2}$ Carol Davila University of Medicine anf Pharmacy Carol DavilaPremier Hospital, 113 Calea Aradului, 300643, Timisoara, Romania \\ ${ }^{3}$ Victor Babes University of Medicine and Pharmacy, Department XIII, Discipline of Neonatology, 2 Eftimie Murgu Sq., 300041, \\ Timisoara, Romania \\ ${ }^{4}$ Victor Babes University of Medicine and Pharmacy, Endocrinology Discipline, 2 Eftimie Murgu Sq., 300041, Timisoara, Romania \\ ${ }^{5}$ Victor Babes University of Medicine and Pharmacy, Department XIII of Obstetrics and Gynecology Discipline, 2 Eftimie Murgu \\ Sq., 300041, Timisoara, Romania \\ Victor Babes University of Medicine and Pharmacy, Department of Hematology, 2 Eftimie Murgu Sq., 300041, Timisoara, \\ Romania \\ ${ }^{7}$ Western University Vasile Goldis Arad, 94 Revolutiei Blvd., 310025, Arad, Romania \\ ${ }^{8}$ Victor Babes University of Medicine and Pharmacy, Department III of Medical Informatics and Biostatistics, 2 Eftimie Murgu Sq., \\ 300041, Timisoara, Romania
}

\begin{abstract}
Procalcitonin was proposed to have been a more specific and better value compared to CRP as a marker of prognosis, although its diagnostic value is also contested. This study was conducted in the Department of Neonatology and the Department of Obstetrics and Gynecology of "Pius Brînzeu" Emergency County Hospital Timisoara on a group of 20 newborns coming from 20 mothers that have been found with low procalcitonin. The gestational age at birth was 36-39 weeks. PCT values do not correlate and do not indicate correctly viral infections. Serum PCT levels must be interpreted within the clinical setting; there are many other causes that could lead to its growth. Our study consists of two different parts. In the first part we computed a regression model in order to see if there is any association between the vales of procalcitonin obtained from the blood analysis of the mother and the procalcitonin of her child.
\end{abstract}

Keywords: procalcitonin levels, inflammatory and specific marker, infection

Procalcitonin levels reflect the degree of systemic inflammatory response. PCT became visible in 2-4 $\mathrm{h}$ after the triggering event, reaching its maximum levels after 12-24 h. In the absence of a persistent stimulus PCT is eliminated, having a half-life of 24-35 h.Thus, this parameter can be used to monitor the dynamics of newborns [1]. Compared with other inflammatory markers (IL1B, IL-6, CRP, ESR), PCT has certain advantages:

- Itgrows rapidly, within 3-6 $\mathrm{h}$ from the onset of infection;

-It is a specific marker for the bacterial etiology;

-It can be correlated with an increased severity of infection and is not influenced by the use of non-steroidal anti-inflammatory drugs or corticosteroid [2].

The results of meta-analysis of two studies published in the last 10 years have confirmed the superiority of PCT compared with other inflammatory markers. [3-4] The first study, published in 2006 by Uzzan et al., reviewed 25 studies (a total of 2966 patients), and reported a sensitivity of PCT between 42 and $100 \%$ with a specificity of 48 to $100 \%$; these results have been confirmed by the metaanalysis of Tang et al. on other 18 studies [5-6]. Procalcitonin has been studied extensively in recent years. Its usefulness as diagnostic marker in critically ill patients sepsis was recently evaluated by two meta-analyzes of the studies published so far [7-10].

\section{Experimental part}

Material and methods

This study was conducted in the Department of Neonatology and the Department of Obstetrics and Gynecology of Pius Brinzeu Emergency County Hospital Timisoara on a group of 20 newborns coming from 20 mothers thathave been found with low procalcitonin. Varsta gestationala la care a avut loc nasterea a fost de 36-39 s. The gestational age at birth was 36-39 weeks.

For the statistical analysis we used the programs Microsoft Excel and SPSS v17. For the Person coefficients, the determination coefficients and the associated $p$-values we used the Regression Model.

\section{Results and discussions}

PCT values do not correlate and do not indicate correctly viral infections. Serum PCT levels must be interpreted within the clinical setting; there are many other causes that could lead to its growth [10-15].

Our study consists of two different parts. In the first part we computed a regression model in order to see if there is any association between the vales of procalcitonin obtained from the blood analysis of the mother and the procalcitonin of her child. For the first part we considered to different samples the mothers and their children's ( 20 in each group). On this sample we have a strong positive correlation $(r=0.86)$, extremely significant $(p<0.001)$. All the results are presented in table 1 and in figure 1 .

For the second part we computed an analysis in order to see if there is any association between the Esbach Proteinuria obtained from the mothers urinary testand her gestational period (calculated in weeks), respectively the Apgar score that the child received. For this part we included 23 patients in the study. We obtained that we have a negative strong correlation, extremely significant $(p<0.001)$ in both cases. All the results are presented in table2, and in figure 2 and figure 3.

\footnotetext{
* email: stoian.dana@umft.ro;,Phone: 0722646085; dr.petreizabella@yahoo.com,Phone: 0742012681
} 
The association between the vales of procalcitonin obtained from the blood analysis of the mother and the procalcitonin of her child

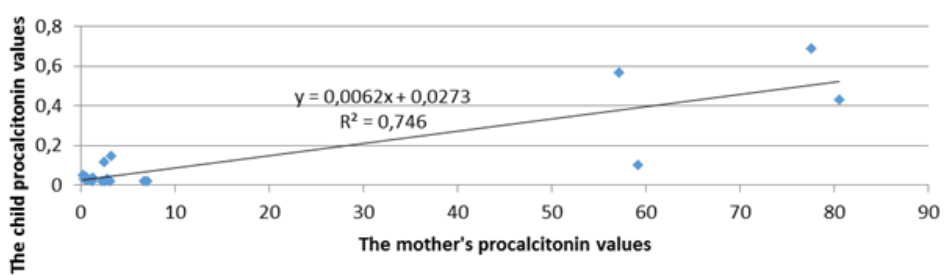

Fig.1. The regression model which presents the association between the vales of procalcitonin obtained from the blood analysis of the mother and the procalcitonin of her child

\begin{tabular}{|c|c|}
\hline The statistical parameters & The values obtained \\
\hline \multicolumn{2}{|c|}{ Results for Esbach Proteinuria compared to the Gestational Period } \\
\hline$r$ (Pearson coefficient) & -0.708 \\
\hline$R^{2}$ & 0.501 \\
\hline $\mathrm{p}$ value & $<0.001$ \\
\hline \multicolumn{2}{|c|}{ Results for Esbach Proteinuria compared to the Apgar Score } \\
\hline r (Pearson coefficient) & -0.770 \\
\hline s & 0.593 \\
\hline $\mathrm{p}$ value & $<0.001$ \\
\hline
\end{tabular}

Table 1

THE REGRESSION MODEL WHICH PRESENTS THE ASSOCIATION BETWEEN THE VALUES OF PROCALCITONIN OBTAINED FROM THE BLOOD ANALYSIS OF THE MOTHER AND THE PROCALCITONIN OF HER CHILD

\begin{tabular}{|r|r|}
\hline The statistical parameters & $\begin{array}{l}\text { The values } \\
\text { obtained }\end{array}$ \\
\hline $\boldsymbol{R}^{2}$ r (Pearson coefficient) & 0,864 \\
\hline & 0,746 \\
\hline
\end{tabular}

The association between the vales of Esbach Proteinuria and the Gestational Period

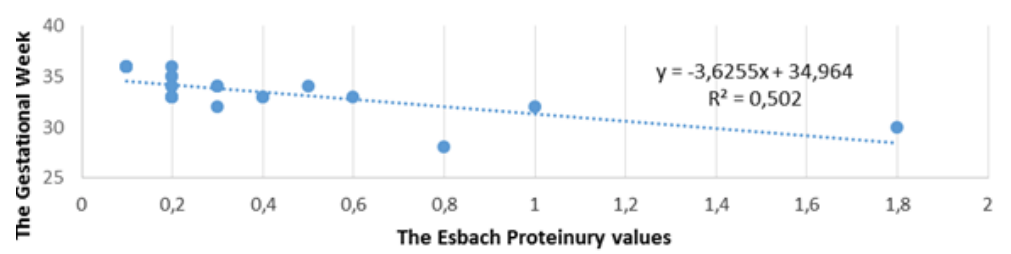

Fig 2. The regression model which presents the association between the values of Esbach Proteinuria and the Gestational Period (calculated in weeks)

The association between the vales of Esbach Proteinuria and the Apgar Score

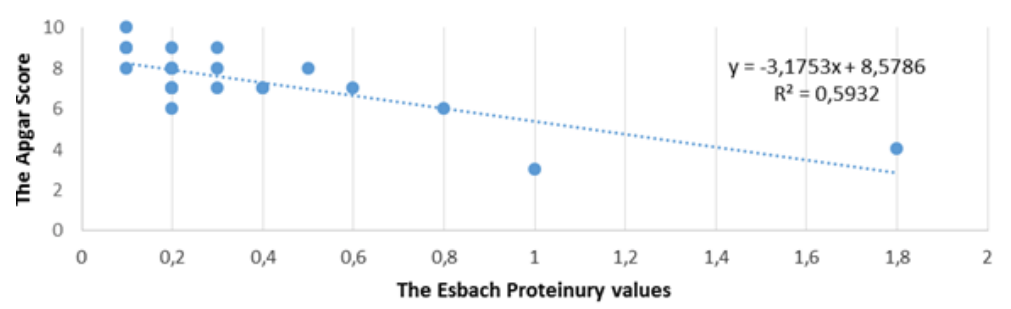

Table 2

THE REGRESSION MODEL WHICH PRESENTS THE ASSOCIATION BETWEEN THE VALUES OF ESBACH PROTEINURIA AND THE GESTATIONAL PERIOD

(CALCULATED IN WEEKS), RESPECTIVELY THE APGAR SCORE

\section{Conclusions}

PCT serum level will be much greater as the infection progresses to severe sepsis or septic shock, unlike the other inflammatory markers which will present only intermittent increases, regardless of the severity of future evolution of the disease. Another advantage is represented by the kinetics of PCT that has a rapid growth in about $6 \mathrm{~h}$ from the onset of microbial invasion, having a half-life of $24 \mathrm{~h}$. Procalcitonin was proposed to have been a more specific and better value compared to CRP as a marker of prognosis, although its diagnostic value is also contested.

\section{References}

1.RIVERS, E., NGUYEN, B., HAVSTAD, S. et al. N Engl J Med, 345, 2001, p. 1368.

2.TANG, B.M., ESLICK, G.D., CRAIG, J.C., MCLEAN, A.S. Lancet Infectious Diseases, 7, 2007, p. 210.

3.DIMA, M., IACOB, D., DUTA, C., PANTEA, S., MARGINEAN, O., BERNAD, E., CRAINA, M., BOGLUT, A., PETRE, I. Rev. Chim. (Bucharest), 67, no. 3,2016, p. 557

4.UZZAN, B., COHEN, R., NICHOLAS, P. et al. Crit Care Med, 34, 2006, p. 1996.
5.PETRE, I., BERNAD, E., CRAINA, M., CITU, C., BOLINTINEANU, S., POP, E., STOIAN, D., SIPOS, S., LUNGEANU, D., FURAU, C., FURAU, G., PANTEA, S., IONITA, I. Rev .Chim. (Bucharest), 67, no. 11, 2016, p. 6.IONITA, I., GRIGORITA, L.,BACEAN MILOICOV, C., PETRE, I.,BERNAD, E., CRAINA, M., DIACONU, M., CITU, C., RADU, F., OROS, D.,BOGLUT, A., FURAU, G., ENATESCU,V., Rev .Chim. (Bucharest), 67, no. 12, 2016, p. 2643.

7.MAKKAR, M., GUPTA, C., PATHAK, R., GARG, S., MAHAJAN, N.C. J Clin Neonatol, 2(1), 2013, p. 25.

8.RODWELL, R.L., LESLIE, A.L., TUDEHOPE, D.I. J Pediatr, 112(5), 1988, p. 761.

9.POLIN, R.A., RANDIS, T.M. Genome Med, 2(9), 2010, p. 58. 10.KHAIR, K.B., RAHMAN, M.A., SULTANA, T., ROY, C.K., RAHMAN, M.Q., AHMED, A.N. Mymensingh Med J, 21(1), 2012, p. 85.

11.TANG, B.M., ESLICK, G.D., CRAIG, J.C., MCLEAN, A.S. Lancet Infect Dis. 2007;7(3):210-217.12.LUZZANI, A., POLATI, E., DORIZZI, R., RUNGATSCHER, A., PAVAN, R., MERLINI, A. Critical Care Medicine. 31(6), 2003, p. 1737.13.CHIESA, C., PANERO, A., ROSSI, N. et al. Clin Infect Dis. 26(3), 1998, p. 664-672.14.

WHICHER, J., BIENVENU, J ., MONNERET, G. Ann Clin Biochem. 38(5), 2001, p. 483.15.PAVCNIK-ARNOL, M., HOJ KER, S., DERGANC, M. Intensive Care Med. 30(7), 2004, p. 1454

$\overline{\text { Manuscript received: } 15.06 .2017}$ 